\title{
СИСТЕМА ДЛЯ ОБЛІКУ ДОНОРСЬКОЇ КРОВІ ТА ІІЇ КОМПОНЕНТІВ
}

\author{
В. 3. Стецюк, А. М. Чиж, Л. Ю. Бабінцева ${ }^{1}$, М. В. Чиж, І. П. Муха \\ Національний технічний університет України \\ «Київський політехнічний інститут імені Ігоря Сікорського» \\ ${ }^{1}$ Національна медична академія післядипломної освіти імені П. Л. Шупика
}

\begin{abstract}
Представлено основні компоненти комп'ютерного десктопного програмного забезпечення для оптимізації процесу обліку та автоматизації статистичного аналізу руху донорської крові та її компонентів на станції переливання крові. Об'єктом дослідження стала база даних електронної медичної облікової документації Черкаської обласної станції переливання крові, способи оброблення інформації, спрямовані на отримання оперативної та періодичної статистичної звітності з використанням основних елементів архітектури Microsoft SQL Server.
\end{abstract}

Ключові слова: станція переливання крові, кров та її компоненти, статистична звітність, база даних.

\section{SYSTEM FOR ACCOUNTING OF THE DONOR BLOOD AND ITS COMPONENTS}

\author{
V. Z. Stetsyuk, A. M. Chyzh, L. Yu. Babintseva ${ }^{1}$, M. V. Chyzh, I. P. Muha \\ National Technical University of Ukraine «Igor Sikorsky Kyiv Polytechnic Institute» \\ ${ }^{1}$ Shupyk National Medical Academy of Postgraduate Education
}

\begin{abstract}
Background. Every fourth inhabitant of the planet needs to use the blood components at least once during the life.
After studying and analyzing the problems of this field, we decided to develop a computer program for optimizing the process of accounting and automation of statistical analysis of blood flow at blood transfusion stations.

The purpose of this work is to develop a computer desktop application «System for accounting of the donor blood and its components».

Materials and methods. The research material is the basic processes of operation of the blood transfusion station which deals with the collection of the necessary biological materials and the supply of blood and its components to medical institutions and individual patients.

Results. The result of the research of the blood transfusion station staff and the analysis of the required accounting documentation is a system that optimizes the work of the station staff.

Applied computer program is installed on any number of computers in the department, integrated into the local network. The database is installed on the server or one of the computers on the local network.

The program incarnates the following functions: accounting for receipt and write-off and blood and its components; filtering biological materials according to the selected criteria; dynamic management of the availability of the necessary position; saving basic information about each position; formation of reporting for specified periods with the possibility of viewing and printing information according to certain indicators; visualization of the results of statistical analysis using diagrams of different types.

Conclusions. The main result of the work is the program, which ensures optimization of the work of blood transfusion station staff.
\end{abstract}

Key words: blood transfusion station, blood and its components, statistical reporting, database.

\section{СИСТЕМА ДЛЯ УЧЁТА ДОНОРСКОЙ КРОВИ И ЕЁ КОМПОНЕНТОВ}

\author{
В. З. Стецюк, А. М. Чиж, Л. Ю. Бабинцева, М. В. Чиж, И. П. Муха \\ Национальный технический университет Украины \\ «Киевский политехнический институт имени Игоря Сикорского» \\ ${ }^{1}$ Национальная медицинская академия последипломного образования имени П. Л. Шупика
}

\begin{abstract}
Представлены основные компоненты компьютерного десктопного программного обеспечения для оптимизации процесса учета и автоматизации статистического анализа движения донорской крови и ее компонентов на станции переливания крови. Объектом исследования стала база данных электронной медицинской учетной документации Черкасской областной станции переливания крови, способы обработки информации, направленные на получение оперативной и периодической статистической отчетности с использованием основных элементов архитектуры Microsoft SQL Server.
\end{abstract}

Ключевые слова: станция переливания крови, кровь и её компоненты, статистическая отчетность, база данных.

(с) В. З. Стецюк, А. М. Чиж, Л. Ю. Бабінцева, М. В. Чиж, І. П. Муха 
Вступ. За даними Всесвітньої організації охорони здоров'я (ВОО3), майже кожен четвертий мешканець планети бодай один раз упродовж життя потребує застосування компонентів крові. Українці в цьому плані не $\epsilon$ винятком, особливо якщо враховувати рівень захворюваності населення, вітчизняну статистику ДТП та нинішні події на сході України.

У сучасних умовах компоненти крові (їх декілька десятків найменувань) застосовують для лікування цілого спектра захворювань, зокрема й хронічних. Тому відповідно до нормативної документації ВООЗ запаси донорської крові в кожній державі мають формуватися з розрахунку 33 донації на 1000 населення. В Україні цей показник не досягає й 12. Та головна проблема не лише в кількості донорської крові, а й в якості виготовлених із неї компонентів та в їх розподілі.

Після вивчення проблематики даної сфери виникла ідея створення програмного забезпечення для оптимізації обліку, а також автоматизації статистичного аналізу руху крові на станції переливання крові з метою покращення рівня обліку та звітності. Впровадження даної програми передбачає полегшення роботи медичних сестер, що ведуть документацію з надходження, витрат або абсолютного браку крові; контроль за дотриманням інструкції з виготовлення, використання та забезпечення якості компонентів крові відповідно до наказу Міністерства охорони здоров'я України від 17.12.2013 № 1093; зменшення ймовірності виникнення помилок при формуванні звітності та втрат даних про зміну кількості крові та її компонентів у банку крові. Головною перевагою впровадження програми $\epsilon$ зменшення часу на рутинну роботу з медичною документацією, оформлення даних про надходження, використання або списання абсолютного браку крові, що, в свою чергу, забезпечує кращу точність та якість результату.

Мета роботи: створення комп'ютерної десктопної програми «Система для обліку руху крові та ї̈ компонентів» із функціями медичного документообігу, формуванням звітності та статистичних показників щодо обліку руху крові та ії компонентів із збереженням набору основної інформації по кожній позиції за вказані проміжки часу тощо.

Предметом дослідження стала реляційна локальна база даних формату SQL Server та основні компоненти архітектури Microsoft SQL Server. Об'єкт дослідження - база даних електронної медичної облікової документації Черкаської обласної станції переливання крові, способи оброблення інформації та формування необхідної звітності (з використанням основних елементів архітектури Microsoft SQL Server).

Матеріал і методи дослідження. Основні процеси роботи станції переливання крові, зокрема забір необхідних біологічних матеріалів і забезпечення кров’ю та її компонентами закладів охорони здоров'я та окремих пацієнтів.

Результати та їх обговорення. Результатом дослідження роботи працівників відділення станції переливання крові та аналізу необхідної облікової документації став програмний продукт, що оптимізує роботу персоналу станції.

Розроблена комп’ютерна програма «Система для обліку руху крові та ії компонентів» (рис. 1) встановлюється на одному або декількох комп'ютерах станції переливання крові. Оператором даної програми $€$ медична сестра, яка веде облік крові та їі компонентів. Це прикладне програмне забезпечення передбачає отримання медичної та статистичної звітності.

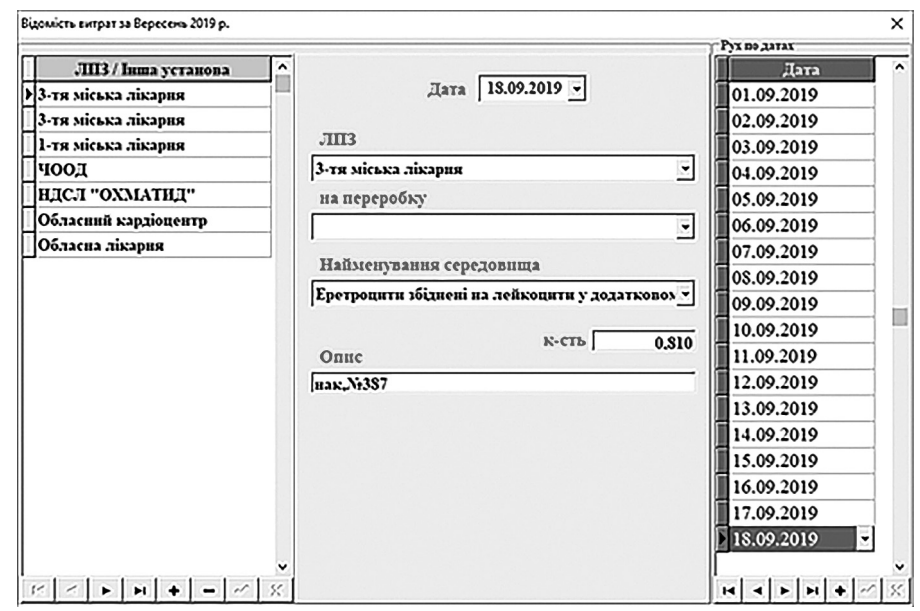

Рис. 1. Зображення з екрану монітора програмного забезпечення 
Програма реалізує такі функції:

- облік надходження крові та її компонентів (із зазначенням найменування середовища, джерела надходження);

- облік витрат крові та їі компонентів (із зазначенням найменування середовища, джерела призначення);

- фільтрація біологічних матеріалів за обраними критеріями:

- за групами крові;

- за видом матеріалу: кров, плазма, тромбоцити, еритроцитарна маса тощо;

- збереження основної інформації про кожну позицію;

- динамічне управління наявністю необхідної позиції;

- формування звітності за певні періоди з можливістю перегляду та друку інформації за показниками;

- візуалізація результатів статистичного аналізу із застосуванням діаграм різного виду.

Користувач програми може виконувати такі дії:

- створення/видалення/редагування запису про найменування середовища;

- перегляд відомостей по кожному найменуванню середовища;

- пошук організації за назвою чи ії частиною;

- фільтрація найменування середовища за видом, групою (для крові), джерелом надходженням, місцем призначення, регіоном, датою надходження/ списання;

\section{Література.}

1. Наказ Міністерства охорони здоров'я України 17.12.2013 № 1093 «Про затвердження Інструкції з виготовлення, використання та забезпечення якості компонентів крові».

2. Документация по SQL Server. - [Електронний ресурс]. - Режим доступу: https://goo.gl/VrWkUY.

3. Bruce Eckel Thinking in C++, Volume One: Introduction to Standard C++ (2nd Edition)/ Eckel Bruce. - Prentice Hall, 2000. - $814 \mathrm{p}$.

4. Learning SQL. SECOND EDITION / Beaulieu Alan. O’Reilly Media, Inc., 2009. — 335 p.

5. Программирование в С++ Builder / В. С. Романчик, А. Е. Люлькин. - Минск, 2007. - 128 с.
- створення/видалення/редагування даних про заклади охорони здоров'я;

- друк таких відомостей:

- деталізований звіт — відомість обліку руху крові (звіт, що містить повну інформацію про весь або відфільтрований за найменуванням середовища рух);

- відомість про надходження (звіт, що містить дані про всі або конкретні заклади охорони здоров'я);

- відомість про витрати (звіт, що містить дані про всі або конкретні заклади охорони здоров'я або про кров, що потребує перероблення);

- відомість про абсолютний брак (звіт, що містить дані про всі або конкретні заклади охорони здоров'я).

Для розроблення даного продукту використовувалась мова програмування $\mathrm{C}++$ та середовище програмування Embarcadero C++ Builder XE7. Для збереження даних розроблено відповідну реляційну локальну базу даних формату SQL Server. Для реалізації роботи з базою даних обрано Microsoft SQL Server 2017 Express.

Висновки. Основним результатом стало створення програмного забезпечення «Система для обліку руху крові та її компонентів», що забезпечує оптимізацію роботи медичного персоналу, який відповідає за реєстрацію руху крові, та персоналу станції переливання крові.

Результати проведеної апробації програми вказують на високу ефективність її впровадження.

\section{References.}

1. Order of the Ministry of Health of Ukraine 17.12.2013 № 1093 «On approval of the Instructions for the manufacture, use and quality assurance of blood components». [In Ukrainian].

2. SQL Server Documentation. Access mode: https://goo. $\mathrm{gl} / \mathrm{VrWkUY} /$.

3. Bruce Eckel (2000). Thinking in C++, Volume One: Introduction to Standard C++ (2nd Edition). Prentice Hall, 814 p.

4. Beaulieu Alan (2009). Learning SQL. Second edition. O’Reilly Media, Inc, 335 p.

5. RomanchikV.S., Ljul'kinA. E. (2007). Programmirovanie v S++ Builder. Minsk. [In Russian]. 